\title{
Kalanchoe Blossfeldina Extract as a Green Corrosion Inhibitor for Carbon Steel in $\mathrm{Na}_{2} \mathrm{~S}$-polluted $\mathrm{NaCl}$ Solutions
}

\author{
Samar.Y.Al-Nami ${ }^{1}$, Abd El-Aziz S. Fouda,* \\ ${ }^{1}$ Chemistry Department, Science College for Girls, King Khalid University, Abha, KSA, Email: \\ salnamee@kku.edu.sa \\ ${ }^{2}$ Department of Chemistry, Faculty of Science, Mansoura University, Mansoura-35516, Egypt, \\ *E-mail: asfouda@hotmail.com
}

doi: $10.20964 / 2020.01 .78$

Received: 8 September 2019 / Accepted: 29 October 2019 / Published: 30 November 2019

\begin{abstract}
The potential of Kalanchoe blossfeldina extract (KBE) as a corrosion inhibitor of carbon steel (CS) in polluted $\mathrm{NaCl}$ solution $(3.5 \% \mathrm{NaCl}+16 \mathrm{ppm} \mathrm{Na} 2 \mathrm{~S})$ was determined utilizing AC impedance (EIS), potentiodynamic polarization (PP) and mass loss (ML) methods. Scanning electron microscopy with energy dispersive X-ray spectroscopy (SEM-EDX), and atomic force microscope (AFM) analyses were used to examine the CS surface. The adsorption of this extract follows Temkin isotherm. Maximum protection was achieved $92.6 \%$ at 300 ppm concentration. PP studies discovered that KBE behaved as a mixed-kind inhibitor in polluted $\mathrm{NaCl}$ solution. The inhibition efficiency (IE) of KBE obtained from the ML and electrochemical tests were in excellent agreement.
\end{abstract}

Keywords: Corrosion inhibition, Kalanchoe blossfeldina extract, $\mathrm{HCl}, \mathrm{PP}, \mathrm{EIS}$

\section{$\underline{\text { FULL TEXT }}$}

(C) 2020 The Authors. Published by ESG (www.electrochemsci.org). This article is an open access article distributed under the terms and conditions of the Creative Commons Attribution license (http://creativecommons.org/licenses/by/4.0/). 